\title{
Liquidity Management and Financial Performance: Evidence From Commercial Banks in Botswana
}

\author{
C.R. Sathyamoorthi ${ }^{1}$, Mogotsinyana Mapharing ${ }^{1} \&$ Mashoko Dzimiri ${ }^{2}$ \\ ${ }^{1}$ Faculty of Business, University of Botswana, Gaborone, Botswana \\ ${ }^{2}$ Stockbroker at Akribos Capital Incorporated \\ Correspondence: C.R. Sathyamoorthi, Faculty of Business, University of Botswana, Private Bag 00701, Gaborone, \\ Botswana. Tel: 267-7173-6816. E-mail: sathyamcr@gmail.com
}

Received: May 6, 2020

Accepted: July 8, 2020

Online Published: October 4, 2020

doi:10.5430/ijfr.v11n5p399

URL: https://doi.org/10.5430/ijfr.v11n5p399

\begin{abstract}
The study examined the impact of liquidity management on the financial performance of commercial banks in Botswana. The study used Return on Assets and Return on Equity to measure financial performance. Cash and cash equivalents to total assets ratio, Cash to deposits ratio, Loans to deposits ratio, Loans to total assets ratio, Liquid assets to total assets ratio, and Liquid assets to deposits ratio were used as proxies for liquidity management. The research population was all the 9 commercial banks in Botswana and the study covered a period of 9 years from 2011 to 2019. This descriptive study sourced monthly secondary data from Bank of Botswana Financial Statistics database. Descriptive statistics, correlation and regression analyses were applied to analyse the data. The results from regression analysis show statistically significant positive relationships for Loans to total assets ratio and Liquid assets to total assets ratio with return on assets and return on equity. Loans to deposits ratio and Liquid assets to deposits ratio had statistically significant negative relationships with return on assets and return on equity. Cash and cash equivalents to total assets ratio had statistically insignificant positive relationship with return on assets and return on equity whilst cash to deposits ratio had statistically insignificant negative relationship with return on assets and return on equity. Findings suggest that the commercial banks should try to optimize liquidity variables to boost bank performance. The policy makers also, through the Central Bank, should come up with initiatives such as prescribing minimum liquidity requirements that will help banks to stay profitable.
\end{abstract}

Keywords: liquidity, financial performance, return on assets, return on equity, commercial banks, Botswana

\section{Introduction}

\subsection{Background Information}

Liquidity is critical to the successful running of all organizations, more especially to financial institutions. Liquidity has been identified as one of the most crucial goals of working capital management and central pillar of cash management (Lamberg \& Vålming, 2009). The existence and development of an enterprise is largely dependent on the efficient management of its liquidity. Liquidity and its effective management in the context of banks refer to the ability of banks to meet their financial commitments and maturing obligations within the stipulated time. The survival of commercial banks, therefore, depends largely on the level of liquidity and its deterioration will lead to the erosion of the level of public confidence in the banks.

During the 2007-2009 global financial crises several banks experienced some difficulties because they failed to manage liquidity in a prudent manner. Thus the crisis emphasized the importance of liquidity to the proper functioning of financial markets and the banking sector (Marozva, 2015). According to Pradhan and Shrestha (2016), liquidity risk of banks arises from funding of long-term assets by short-term liabilities, thereby making the liabilities subject to rollover or refinancing risk. Further, the liquidity risk is usually of an individual nature, but in certain situations may compromise the liquidity of the financial system as well (Pradhan and Shrestha, 2016).

Despite the perceived positive impact of liquidity on bank profitability, studies on this matter offer inclusive results. In particular, insufficient liquidity has been found to be one of the major reasons for bank failures especially during crisis as holding liquid assets has an opportunity cost of higher returns. Consequently, a positive and significant 
relationship was found between bank liquidity and profitability (Bourke, 1989). It is noteworthy that in times of instability, banks may choose to increase their cash holding to mitigate risk.

In contrast, Molyneux and Thorton (1992) found a negative correlation between liquidity and profitability. Furthermore, the beta coefficients for liquidity ratio and quick ratio were negative with return on assets and return on equity (Pradhan and Shrestha, 2016). This indicates that increased liquidity ratio and quick ratio decreases the return on assets and return on equity of the bank. Hence, the contrasting results in studies on liquidity and bank performance allude to the need for banks to hold optimal levels of liquidity that will boost bank performance.

In the perspective of Africa, Ibe (2013) investigated the impact of liquidity management on the profitability of banks in Nigeria. Three banks were randomly selected to represent the entire banking industry. The proxies for liquidity management included cash and short term fund, bank balances, and treasury bills and certificates, while profit after tax was the proxy for profitability. The result of this study has shown that liquidity management is indeed a crucial problem in the Nigerian banking industry. The study therefore recommends that banks should engage competent and qualified personnel in order to ensure that right decisions are adopted especially with the optimal level of liquidity and still maximize profit (Ibe, 2013).

In another study closer to Botswana, Marozva (2015) posits that there exists a negative and significant deterministic relationship between net interest margin and funding liquidity risk for South African banks. In particular, this study explored this relationship in the context of the market liquidity risk and funding liquidity risk for South African banks for the period between 1998 and 2014. The results show an insignificant co-integrating relationship between net interest margin and the two measures of liquidity.

Studies measuring liquidity (in isolation) and bank performance in the context of Botswana have been limited in literature. Most studies in Botswana context has measured the impact of liquidity amongst other independent variables, with argument being that liquidity is not the only factor affecting bank performance. These determinants have been categorized into internal and external factors. The internal factors refer to bank-specific factors that can be controlled by the banks' management while external factors considered are the macroeconomic factors such as GDP, inflation and money supply. Still, contrasting results have been found on the liquidity variable and profitability even when assessed among other variables. For example, Sathyamoorthi, Mapharing, Ndzinge, Tobedza, and Wally-Dima (2017) assessed the performance of Listed Commercial Banks in Botswana using the Camel Model, and the results were that the impact of the liquidity position on the performance of selected banks was positive and significant. In contrast, a negative and significant relationship was obtained between liquidity (among other variables) with bank profitability in Botswana for a period from 2004 to 2013, using ordinary least square technique (Seemule, Sinha and Ndlovu, 2017). Other studies in Botswana context which assessed the impact of liquidity (among other independent variables) on bank performance and yielded conflicting results include, among others: (Sathyamoorthi, Mapharing, Mphoeng, \& Dzimiri, 2019; Mbekomize \& Mapharing, 2017; Ndlovu, 2015; Amusa \& Kayawe, 2003).

\subsection{Banking Sector Liquidity in Botswana}

According to Bank of Botswana Financial Stability Report (2019), the Botswana banking sector has sufficient liquidity. In particular, total market liquidity has increased, rising from P11.2 billion in December 2017 to P13.2 billion in December 2018. However, it was virtually unchanged at P13.3 billion in June 2019. Further, the report indicates that liquidity ratio of the banks increased from 16.6 percent in December 2017 to 17.8 percent in December 2018, but declined slightly to 17.7 percent in June 2019. Nevertheless, the ratio was significantly higher than the prudential requirement of 10 percent. Therefore, this outcome shows a liquid banking system in Botswana. It is also worth noting that the commercial banks' funding structure continues to be dominated by business deposits with a 70.6 percent and 69.1 percent of total deposits in December 2018 and June 2019 respectively. As such, this raises concerns of imbalance in the market and potential increase in funding costs due to the volatility of business deposits. In particular, the ratio of large deposits to total deposits has averaged 40 percent over the last three years up to 2018 . As shown in the Botswana Financial Stability Report (2018), this outcome depicts potential funding concentration risk.In spite of the concentration risk concern, the liquidity position of the banks continue to improve. Overall, it has been found that the capital, asset quality, liquidity and profitability levels that meet prudential requirements for banks indicate a generally sound and stable financial system (Monetary Policy Statement, 2020). Due to this positive outlook, the question that arises is whether the positive liquidity levels will translate into positive profits for commercial banks, a phenomenon that has led to the motivation of this study. 


\subsection{Problem Statement}

Several studies have concluded that liquidity status of banks play an important role in commercial bank performance. However, other studies have pointed out to the contrary. It is on the backdrop of the limited focal studies on this subject matter, the inconclusive results of the comprehensive studies that measure the impact of liquidity (among other variables) on bank profitability, and the stable liquidity among banks in Botswana, that a more focused study that measures liquidity (in isolation) and using more recent data be conducted to provide more concrete evidence. Studies have showed that liquidity position of commercial banks in Botswana has been positive and above prudential requirements (Botswana Financial Stability Report, 2019). Thus, the overarching question is whether this positive liquidity stance by commercial banks in Botswana will translate into positive profits. This is expected to arrest the inconsistencies in the outcome of studies that assess liquidity factors on bank profitability.

Based on the above problem, the following research questions are developed to assess the impact of liquidity on commercial bank performance in Botswana:

\subsection{Research Questions}

What is the likely impact of:

1. Cash and cash equivalents to total assets ratio on bank financial performance?

2. Cash to deposits ratio on bank financial performance?

3. Loans to deposits ratio on bank financial performance?

4. Loans to total assets ratio on bank financial performance?

5. Liquid assets to total assets ratio on bank financial performance?

6. Liquid assets to deposits ratio on bank financial performance?

\subsection{Significance of the Study}

The literature has alluded to the fact that the survival of commercial banks depends largely on the level of liquidity and its deterioration will lead to the erosion of the level of public confidence in the banks. In addition, virtually every financial transaction or commitment has implications for bank's liquidity. Therefore, the primary objective of the study is to determine the effect of liquidity management on the financial performance of commercial banks in Botswana, and make recommendations for management decision making and policy objectives on the realm of policy makers. The study is also expected to add to the limited literature on the impact of liquidity in commercial banks in the context of Botswana.

\subsection{Research Objectives}

The primary objective of the study is to determine the effect of liquidity management on Commercial bank performance in Botswana. Precisely, the study aims to measure the impact of:

1. Cash and cash equivalents to total assets ratio on return assets and return on equity.

2. Cash to deposit ratio on return on assets and return on equity.

3. Loan to deposits ratio on return on assets and return on equity.

4. Loans to total assets ratio on return on assets and return on equity.

5. Liquid assets to total assets ratio on return on assets and return on equity.

6. Liquid assets to deposits ratio on return on assets and return on equity.

\section{Theoretical and Empirical Perspective}

\subsection{Theoretical Review}

The theoretical framework is a structure that provides an insight to the concepts and theories that are pertinent to the topic of research.

\subsubsection{Liquidity Management}

The term liquidity in the context of banks refers to the capability of a bank to meet its financial obligations as soon as they fall due. Management of liquidity is critical to the successful operations of all organizations, especially of the banking institutions on account of the fact that customer confidence on the banks is largely dependent on the availability of funds on time. From a commercial bank's point of view, liquidity is taken as its ability to meet its contractual obligations on due dates and include in the normal course of business, those lending and investment 
commitments, deposit withdrawals as well as liability maturities (Lartey, Antwi \& Boadi, 2013). Liquidity is seen as a precondition for the daily operation of banks. Liquidity is of significance to banks' both internal and external environments as it is closely related to their day to day operations (Edem, 2017). Deficient liquidity can damage proper functioning of banks as they may fail to meet customer demands for funds on time. This will lead to strained relationships with bank customers and is, therefore, imperative to develop a strategy for efficient liquidity management. This could be in the form of appropriate procedures for measuring, monitoring and managing liquidity (Agbada \& Osuji, 2013). It is therefore, understood that liquidity and its efficient management are the main components for a robust banking system in a country. An effective liquidity management in banks should ensure a good balance between inflows and outflows of cash and the adoption of such a practice among all banks that will lead to the creation of a stable banking sector (Dzapasi, 2020). Efficient liquidity management will guarantee successful business operations, help increase return on assets and improve earnings and capital (Businge, 2017). Banks can achieve liquidity by shortening asset maturities; lengthen liability maturities, issuance of more equity, reduction of contingent commitments etc. The following theories are relevant for the study:

\subsubsection{Shiftability Theory of Liquidity}

Harold G, Moulton in 1915, developed the Shiftability theory. The theory states that banks should invest some of their funds available for investment in securities and credit instruments that have secondary market so that they can be converted to cash as and when a need arises to address declining liquidity. The theory contends that highly marketable securities held by banks is an excellent source of liquidity and that shiftability, marketability or transferability of a bank's assets is a basis for ensuring liquidity (Ibe, 2013).

\subsubsection{The Liquidity Preference Theory}

The theory was developed by Keynes in 1936. According to him the interest rate should be viewed as a monetary matter. It is considered as a return for parting with liquidity and, therefore, the rate of interest is the direct outcome of the demand and supply of money. He underscored that the demand for money are driven by transactionary, precautionary and speculative motives. This means that people keep money to meet with their day to day expenses, sacrifice the interest and keep the funds as a precautionary measure and to meet unforeseen expenses and when interest rates increases; they decide to hold less cash and invest their funds to get more profit. In this theoretical context, it is suggested that banks adopt active balance sheet policies (Onyekwelu, Chukwuani \& Onyeka (2018).

\subsubsection{Trade-off Theory}

According to the theory, a trade-off exists between liquidity and profitability in all organizations. In a bank's context, this means that the two objectives to achieve good profits and maintain liquidity cannot be followed simultaneously without one affecting the other (Akinwumi, Essien \& Adegboyega, 2017). This means that banks should aim at maintaining an optimum level of liquidity to balance between the benefit of holding cash in the form of saving transaction cost to raise funds and the cost of holding cash in the form of tax disadvantage and liquidity premium (Edem, 2017). The theory is relevant for the study as it examines the relationship between liquidity and performance.

\subsubsection{Financial Performance}

The term financial performance generally denotes a measure of an organization's overall financial wealth over a given period of time. It gauges the management efficiency in the use of organizational resources (Ware, 2015). In the context of banks, European Central Bank (2010) recognises bank performance as the capacity to generate sustainable profitability that can guard against unexpected losses, strengthen capital position and help improve future profitability by investing retained earnings.

The relationship between liquidity and performance is critical to banks. It is generally understood that efficiently monitored liquidity levels leads to good financial results. Effective liquidity management creates good public confidence in the financial system of a country and consequently on the liquidity state of banks. This can lead to better return on bank's assets (Onyekwelu, Chukwuani \& Onyeka, 2018). Ibrahim and Aqeel (2017) underscored the need to make optimum use of liquid funds for investments to enhance profitability, keeping aside adequate funds for meeting operational commitments. Excessive levels of liquid funds will negatively affect profitability, while low levels of liquidity can adversely affect the smooth functioning of banks (Ware, 2015). This means that banks should make a trade between liquidity and profitability in order to boost business profit (Bagh, Razzaq, Azad, Liaqat \& Khan, 2017). 


\subsection{Empirical Literature Review}

Literature reveals that a good number of studies have been carried out in numerous research circles globally to determine the effect of liquidity management on the financial performance of commercial banks. Some researchers found a positive impact, while others concluded through their studies a negative effect, while some other researchers found either a weak or no relationship at all. The discussion still continues.

Majakusi (2016) conducted a study on the effect of liquidity management on performance among commercial banks in Kenya and found evidence of positive relationships between cash and cash equivalents to total Assets and equity to net assets Ratios and Return on Assets as proxies of liquidity management and bank profitability respectively. This would mean that adequate cash balance leads to good financial outcomes. A similar study by Sheikhdon (2016), on commercial banks in Mogadishu, Somalia, concluded that liquidity management drivers have a statistically significant positive influence on bank performance. A recent study by Dzapasi (2020) examined the determinants of performance of five leading banks in Zimbabwe and found a strong positive relationship between liquidity management represented by current ratio and bank financial performance. Agbada and Osuji (2013) looked at Nigerian banks to determine the effect of liquidity on bank performance and found a significant relationship. The study highlighted that effective liquidity management can strengthen banks' reliability. Two studies (Edem 2017; Onyekwelu, Chukwuani \& Onyeka 2018) on deposit money banks in Nigeria also revealed a positive impact by liquidity on bank performance. But a later investigation by Ayunku (2017) on liquidity management and bank performance in Nigeria, though confirmed positive impact, found an insignificant relationship between Return on Assets and Liquidity ratio. Similarly, Lartey, Antwi and Boadi (2013), found a weak positive relationship between the liquidity and the profitability of the listed banks in Ghana. Studies on Kenyan Commercial Banks by Kitere, Namusonge and Makokha (2019) confirmed that Liquidity management practices had a positive relationship with performance of Kenyan commercial banks. The study, among other recommendations, suggested that banks should keep minimum liquidity as required by Central Bank and avoid both extremes of excess liquidity and illiquidity. Mucheru, Shukla and Kibachia (2017) also found a significant positive liquidity-performance relationship in selected commercial banks in Rwanda. Islam (2018) also supports the above-mentioned findings in the context of listed banks in Bangladesh. The above findings, however, conflict with Molyneux and Thornton (1992) who concluded in their study that liquidity ratios have a weak inverse relationship with profitability, indicating that liquidity has a mild negative impact on bank performance.

Some researchers on the topic found mixed results in their study on liquidity and profitability. Nabeel and Hussain (2017), in their studies on the banking sector in Pakistan used five independent variables and three dependent variables. Findings revealed a positive significant relationship between liquidity measures of interest coverage and capital adequacy ratios and profitability, whereas cash and current ratios had negative relationship with the banks' performance. A similar investigation by Waleed, Pasha and Akhtar (2016) on Pakistan banks showed mixed results with liquidity ratios having direct impact with Return on Assets and Equity; insignificant effect on Return on Investment; a positive impact on Net profit margin and Tobin's Q and a negative effect on Earnings per share. Study by Ibe (2013) on Nigerian banks also revealed a negative effect of cash and short term funds on profitability of three selected banks and the remaining independent variables had no impact on bank performance. Ibrahim and Aqeel (2017) also reported mixed results of current and investment ratios having a positive impact, whereas capital and liquid assets ratios showing a negative impact on the performance of commercial banks in Pakistan. Negative significant impact of Cash-deposit, credit-deposit and investment deposit ratios on Return on Assets and no significant effect on Return on Equity were detected by Mishra and Pradhan (2019) in private sector banks in India. On the other hand, Bagh, Razzaq, Azad, Liaqat and Khan (2017) reported a positive effect of advance to deposit, cash deposit and deposit asset ratios on return on assets with a negative effect on return on equity. Again, investigation by Akinwumi, Essien and Adegboyega (2017) revealed mixed results of significant relationship between current ratio and Return on equity, but not that all significant with Return on Assets. Sandino (2019) examined listed banks in Ghana and the study generated mixed results. Salim and Bilal (2016), in their study on Omani banks used four dependent variables and six independent variables and found significant relationships except between bank liquidity and one dependent variable viz. Net interest margin.

On the other hand, some research on the topic highlighted insignificant or no impact of liquidity on profitability. A study by Marozva (2015) reported insignificant relationship between net profit margin and selected measures of liquidity in South African banks. In a similar study, Molefe and Muzindutsi (2016) found no impact of banks' profitability on major South African banks. Sile, Olweny and Sakwa (2019) looked at banks in Kenya and found no statistically significant effect of liquidity on performance. Similar results were disclosed by Shrestha (2018) in their study on Nepalese commercial banks. 
Based on the above observations, it could be concluded that the impact of liquidity on financial performance among financial institutions remain vague and this calls for further research on the topic.

\section{Methodology}

\subsection{Research Design, Data and Sampling}

The study focused on determining the impact of liquidity management on the financial performance of all commercial banks in Botswana. The study has adopted a panel data methodology (2011-2019) and an analytical and descriptive research design. The study sourced monthly secondary data from Bank of Botswana Financial Statistics (BFS) database. It covered a nine-year monthly data from January 2011 to December 2019. This dataset has resulted in a total of 108 observations (9 years* 12). The latest period possible was of keen interest, and convenience-sampling technique was thus applied based on data availability for all the variables under study.

Secondary data collected comprised of aggregate data for a population of all commercial banks in Botswana for the period under study. There are currently 9 commercial banks operating in Botswana and these are; African Banking Corporation of Botswana Limited (trading as 'BancABC'), Bank Gaborone Limited, Bank of Baroda (Botswana) Limited, ABSA (Botswana) Limited, First Capital Bank Limited, First National Bank of Botswana Limited, Stanbic Bank Botswana Limited, Standard Chartered Bank Botswana Limited, and State Bank of India (Botswana) Limited (Bank of Botswana, 2019).

\subsection{Variables}

The dependent variable was measured by Return on Total Assets (ROA) and Return on Equity (ROE) and, independent variables for the study include Cash and cash equivalents to total assets ratio, Cash to deposits ratio, Loans to deposits ratio, Loans to total assets ratio, Liquid assets to total assets ratio and Liquid assets to deposits ratio. Income growth and size measured by the natural logarithms of total assets were the control variables. These variables were adopted for the study from similar studies as presented in Table 1.

Table 1. Variables

\begin{tabular}{|c|c|c|c|}
\hline Variables & Abb. & Explanation & Authors and year of publication \\
\hline Return on Assets & ROA & $\begin{array}{l}\text { Indicates how much profits a business } \\
\text { able to generate from its assets. }\end{array}$ & $\begin{array}{l}\text { Majakusi (2012); Song'e (2015); Nabeel, and Hussain (2017); Akenga } \\
\text { (2015); Pasha (2016); Ibrahim, and Aqeel (2017); Mishra, and Pradhan } \\
\text { (2019); Molefe, and Muzindutsi (2016); Bagh, Razzaq, Azad, Liaqat, } \\
\text { and Khan (2017); Maqsood, Anwar, Raza, Ijaz and Shouqat (2016); } \\
\text { Akinwumi, Micheal and Raymond (2017); Sile, Olweny and Sakwa } \\
\text { (2019); Ayunku (2017); Shrestha (2018); Sandino (2019); Salim and } \\
\text { Bilal (2016); and Osei (2019) }\end{array}$ \\
\hline Return on Equity & ROE & $\begin{array}{l}\text { Measures the profits of a business in } \\
\text { relation to its equity. }\end{array}$ & $\begin{array}{l}\text { Dzapasi (2020); Nabeel and Hussain (2017); Pasha (2016); Ibrahim and } \\
\text { Aqeel (2017); Mishra and Pradhan (2019); Molefe, and Muzindutsi } \\
\text { (2016); Bagh, Razzaq, Azad, Liaqat and Khan (2017); Akinwumi, } \\
\text { Micheal and Raymond (2017); Edem (2017); Salim and Bilal (2016); } \\
\text { and Osei (2019) }\end{array}$ \\
\hline $\begin{array}{l}\text { Cash and cash } \\
\text { equivalents to } \\
\text { total assets }\end{array}$ & CCTA & $\begin{array}{l}\text { Shows that part of business assets } \\
\text { which are held as cash and cash } \\
\text { equivalents. A high ratio displays the } \\
\text { degree of safety and excess cash is a } \\
\text { sign of inefficiency. }\end{array}$ & $\begin{array}{l}\text { Majakusi (2012); Song'e (2015); and Bagh, Razzaq, Azad, Liaqat and } \\
\text { Khan (2017) }\end{array}$ \\
\hline Cash to deposits & $\mathrm{CD}$ & $\begin{array}{l}\text { A high ratio informs customers on } \\
\text { bank's liquidity strength to return } \\
\text { their deposits if they ask for. It also } \\
\text { denotes what percentage of deposits } \\
\text { received were lent out. }\end{array}$ & $\begin{array}{l}\text { Mishra \& Pradhan (2019); Bagh, Razzaq, Azad, Liaqat \& Khan (2017); } \\
\text { and Osei (2019) }\end{array}$ \\
\hline Loans to deposits & LD & $\begin{array}{l}\text { A high ratio indicates that the bank } \\
\text { does not have adequate funds to meet } \\
\text { unforeseen contingencies. A low } \\
\text { ratio, on the other hand is seen as a }\end{array}$ & $\begin{array}{l}\text { Song'e (2015); Mishra and Pradhan (2019); Bagh, Razzaq, Azad, } \\
\text { Liaqat and Khan (2017; Edem (2017); Marozva (2015); Shrestha } \\
\text { (2018); Sandino (2019); and Osei (2019) }\end{array}$ \\
\hline
\end{tabular}




\begin{tabular}{|c|c|c|c|}
\hline & & sign of inefficiency. & \\
\hline $\begin{array}{l}\text { Loans to total } \\
\text { assets }\end{array}$ & LTA & $\begin{array}{l}\text { A high ratio is a sign of high risk as } \\
\text { loans are less liquid. It also, however, } \\
\text { indicates that the bank will have high } \\
\text { profits through high interest income. }\end{array}$ & Sandino (2019); and Salim \& Bilal (2016) \\
\hline $\begin{array}{l}\text { Liquid assets to } \\
\text { total assets }\end{array}$ & LATA & $\begin{array}{l}\text { The ratio provides an indication of the } \\
\text { bank's liquid funds' availability to } \\
\text { honour expected and unexpected } \\
\text { demands for cash }\end{array}$ & Onyekwelu, Chukwuani and Onyeka (2018); and Salim \& Bilal (2016) \\
\hline $\begin{array}{l}\text { Liquid assets to } \\
\text { deposits }\end{array}$ & LAD & $\begin{array}{l}\text { Indicates a bank's liquidity level } \\
\text { funded by deposits. A low ratio } \\
\text { suggests that the bank is susceptible } \\
\text { to liquidity risk; whereas a high ratio } \\
\text { is a sign of low interest margin, the } \\
\text { key contributor to a bank's profits. }\end{array}$ & Onyekwelu, Chukwuani and Onyeka (2018); and Salim \& Bilal (2016) \\
\hline Size & SIZE & $\begin{array}{l}\text { Natural logarithms of total assets for } \\
\text { commercial banks }\end{array}$ & Song'e (2015); Islam (2018); and Osei (2019) \\
\hline Income growth & GROWTH & $\begin{array}{l}\text { It's a percentage change in total } \\
\text { income of commercial banks from } \\
\text { one year to the other. A positive } \\
\text { growth indicates an increase in the } \\
\text { income/revenue of commercial banks. }\end{array}$ & Ahmed U., Ahmed, Islam, and Ullah, (2015) \\
\hline
\end{tabular}

\subsection{Research Model for Data Analysis}

Nabeel and Hussain (2017), Pasha (2016) and Salim and Bilal (2016) used more than two dependent variables in determining the impact liquidity of management on financial performance of commercial banks and, Return on Assets (ROA) and Return on Equity (ROE) were also included as the other two dependent variables. The studies of Ibrahim and Aqeel (2017), Mishra and Pradhan (2019), Molefe and Muzindutsi (2016), Bagh, Razzaq, Azad, Liaqat and Khan (2017) and Osei (2019) used two performance measures as their dependent variables being ROA and ROE. However, the studies of Majakusi (2012); Song'e (2015); Akenga (2015); Maqsood, Anwar, Raza, Ijaz \& Shouqat (2016); Sile, Olweny \& Sakwa (2019); Shrestha (2018); and Sandino (2019) used only ROA as the dependent variable whilst ROE was used alone as the dependent variable by Dzapasi (2020); and Edem (2017). ROA and ROE were used as dependent variables for the study considering that they were most commonly used variables by previous studies.

According to Abdallah, Goergen, and O'Sullivan, (2015) endogeneity is a problem that arises, when there is correlation between independent variables and error term in regression. Endogeneity may be caused by excluding some independent variables during regression and dependent variable being affected by one or more independent variables that in turn are determined by the dependent variable (Abdallah, Goergen, \& O'Sullivan, 2015). The study used all the independent and control variables used in similar studies presented in Table 1 to ensure that some explanatory variables were not omitted. The study utilized three stage regression analysis as adopted from Ahmed U., Ahmed, Islam, and Ullah, (2015) and this resulted there being six regression models as illustrated in Regression Analysis Section under Data analysis and Discussion of Findings.

Model: The basic core regression models for the study are presented in equation 1 and 2:

$$
\begin{aligned}
& \mathrm{ROA}_{i \mathrm{it}}=\alpha+\beta_{1} \mathrm{CCTA}_{\mathrm{it}}+\beta_{2} \mathrm{CD}_{\mathrm{it}}+\beta_{3} \mathrm{XLD}_{\mathrm{it}}+\beta_{4} \mathrm{LTA}_{\mathrm{it}}+\beta_{5} \mathrm{LATA}_{\mathrm{it}}+\beta_{6} \mathrm{XLAD}_{\mathrm{it}}+\beta_{7} \mathrm{SIZE}_{\mathrm{it}}+\beta_{8} \mathrm{GROWTH}_{\mathrm{it}}+\varepsilon \\
& \mathrm{ROE}_{\mathrm{it}}=\alpha+\beta_{1} \mathrm{CCTA}_{\mathrm{it}}+\beta_{2} \mathrm{CD}_{\mathrm{it}}+\beta_{3} \mathrm{XLD}_{\mathrm{it}}+\beta_{4} \mathrm{LTA}_{\mathrm{it}}+\beta_{5} \mathrm{LATA}_{\mathrm{it}}+\beta_{6} \mathrm{XLAD}_{\mathrm{it}}+\beta_{7} \mathrm{SIZE}_{\mathrm{it}}+\beta_{8} \mathrm{GROWTH}_{\mathrm{it}}+\varepsilon
\end{aligned}
$$

Where;

$\alpha=$ constant $; \varepsilon=$ error term 


\section{Data Analysis and Discussion of Findings}

The data for the study was analyzed using Statistical Package for Social Sciences (SPSS). Regression and correlation analysis, descriptive and inferential statistics were applied to analyze the data. In the regression analysis, financial performance, which is the dependent variable, was measured by Return on Total Assets (ROA) and Return on Equity (ROE) respectively. Independent variables comprised of selected Liquidity management ratios of; Cash and cash equivalents to total assets ratio (CCTA), Cash to deposits ratio (CD), Loans to deposits ratio (LD), Loans to total assets ratio (LTA), Liquid assets to total assets ratio (LATA), and Liquid assets to deposits ratio (LAD). Natural logarithms of total assets (SIZE) and income growth (GROWTH) were used as control variables for the regression models.

\subsection{Descriptive Analysis}

Table 2 shows the descriptive statistics of the data used for the study. The median value for ROA is $0.19 \%$ whilst $1.68 \%$ is the median value for ROE. The standard deviations for the dependent variables (ROA and ROE) are small, it shows that the returns data is not widely dispersed over period under consideration. However, there is some dispersion on the data for independent variables; LD, CD, LAD, CCTA, LTA, LATA, SIZE and GROWTH as highlighted by their standard deviations, $8.70 \%, 6.73 \%, 5.95 \%, 5.69 \%, 5.49 \%, 5.21 \%, 8.83 \%$ and $6.83 \%$ respectively.

Distributional property of the data further indicates positive skewness (skewness statistics) for return of equity $(\mathrm{Sk}=$ $0.260)$, cash and cash equivalents to total assets ratio ( $\mathrm{Sk}=1.753)$, cash to deposits ratio ( $\mathrm{Sk}=1.715)$, liquids to total assets ratio $(\mathrm{Sk}=1.831)$, liquid assets to deposits ratio $(\mathrm{Sk}=1.807)$ income growth $(\mathrm{SK}=0.172)$. Ratios of loans to total assets and loans to deposits and, natural logarithms of total assets and return on assets registered negative skewness. Positive skewness indicates that the right tail of the distribution is longer than the left whilst for negative skewness, the left tail of the distribution is longer than the right tail. Therefore, the data for this study is to a greater extent, positively skewed.

However, the values for skewness and kurtosis between -2 and +2 are considered acceptable to prove normal distribution (Muzaffar, 2016; Hanson, 2017). Based on this, the skewness for all the variables for the study are within limits, hence normally distributed.

Table 2. Descriptive statistics

\begin{tabular}{lcccccccccc}
\hline & $\mathrm{N}$ & Minimum & Maximum & Median & Mean & Std. Deviation & \multicolumn{2}{c}{ Skewness } & \multicolumn{2}{c}{ Kurtosis } \\
& & & & & & & & & Std. & \\
& Statistic & Statistic & Statistic & Statistic & Statistic & Statistic & Statistic & Error & Statistic & Std. Error \\
\hline ROA & 108 & -0.0003 & 0.0036 & 0.0019 & 0.0019 & 0.0007 & -0.0580 & 0.2330 & 0.2050 & 0.4610 \\
ROE & 108 & -0.0028 & 0.0379 & 0.0168 & 0.0176 & 0.0072 & 0.2600 & 0.2330 & 0.2700 & 0.4610 \\
CCTA & 108 & 0.0084 & 0.2756 & 0.0699 & 0.8566 & 0.0569 & 1.7530 & 0.2330 & 3.0000 & 0.4610 \\
CD & 108 & 0.0106 & 0.3401 & 0.0904 & 0.1067 & 0.0673 & 1.7150 & 0.2330 & 3.0200 & 0.4610 \\
LTA & 108 & 0.4411 & 0.6659 & 0.6323 & 0.6111 & 0.0549 & -1.6350 & 0.2330 & 1.7610 & 0.4610 \\
LD & 108 & 0.5343 & 0.8762 & 0.8123 & 0.7742 & 0.0870 & -1.3590 & 0.2330 & 0.7890 & 0.4610 \\
LATA & 108 & 0.0929 & 0.3444 & 0.1523 & 0.1660 & 0.0521 & 1.8310 & 0.2330 & 3.5310 & 0.4610 \\
LAD & 108 & 0.1171 & 0.4249 & 0.1974 & 0.2085 & 0.0595 & 1.8070 & 0.2330 & 3.7420 & 0.4610 \\
SIZE & 108 & 10.6935 & 10.9943 & 10.8847 & 10.8502 & 0.0883 & -0.2050 & 0.2330 & -1.2280 & 0.4610 \\
GROWTH & 108 & -0.1828 & 0.2386 & 0.0024 & 0.0061 & 0.0683 & 0.1720 & 0.2330 & 0.7330 & 0.4610 \\
\hline
\end{tabular}




\subsection{Correlation Analysis}

Table 3. Correlations (Pearson Correlation)

\begin{tabular}{|c|c|c|c|c|c|c|c|c|c|c|c|}
\hline & & ROA & ROE & CCTA & $\mathrm{CD}$ & LTA & $\mathrm{LD}$ & LATA & LAD & SIZE & GROWTH \\
\hline \multirow[t]{2}{*}{ ROA } & Correlation & 1 & & & & & & & & & \\
\hline & Sig. (2-tailed) & & & & & & & & & & \\
\hline \multirow[t]{2}{*}{ ROE } & Correlation & $0.984 * *$ & 1 & & & & & & & & \\
\hline & Sig. (2-tailed) & 0.000 & & & & & & & & & \\
\hline \multirow[t]{2}{*}{ CCTA } & Correlation & $0.419^{* *}$ & $0.525^{* *}$ & 1 & & & & & & & \\
\hline & Sig. (2-tailed) & 0.000 & 0.000 & & & & & & & & \\
\hline \multirow[t]{2}{*}{$\mathrm{CD}$} & Correlation & $0.404 * *$ & $0.509 * *$ & $0.999 * *$ & 1 & & & & & & \\
\hline & Sig. (2-tailed) & 0.000 & 0.000 & 0.000 & & & & & & & \\
\hline \multirow[t]{2}{*}{ LTA } & Correlation & $-0.451 * *$ & $-0.573 * *$ & $-0.950 * *$ & $-0.944 * *$ & 1 & & & & & \\
\hline & Sig. (2-tailed) & 0.000 & 0.000 & 0.000 & 0.000 & & & & & & \\
\hline \multirow[t]{2}{*}{ LD } & Correlation & $-0.530 * *$ & $-0.641 * *$ & $-0.925^{* *}$ & $-0.914 * *$ & $0.983^{* *}$ & 1 & & & & \\
\hline & Sig. (2-tailed) & 0.000 & 0.000 & 0.000 & 0.000 & 0.000 & & & & & \\
\hline \multirow[t]{2}{*}{ LATA } & Correlation & $0.398^{* *}$ & $0.500 * *$ & $0.997 * *$ & $0.998 * *$ & $-0.938 * *$ & $-0.911 * *$ & 1 & & & \\
\hline & Sig. (2-tailed) & 0.000 & 0.000 & 0.000 & 0.000 & 0.000 & 0.000 & & & & \\
\hline \multirow[t]{2}{*}{ LAD } & Correlation & $0.358^{* *}$ & $0.459 * *$ & $0.992 * *$ & $0.995 * *$ & $-0.921 * *$ & $-0.881 * *$ & $0.997 * *$ & 1 & & \\
\hline & Sig. (2-tailed) & 0.000 & 0.000 & 0.000 & 0.000 & 0.000 & 0.000 & 0.000 & & & \\
\hline \multirow[t]{2}{*}{ SIZE } & Correlation & $-0.597 * *$ & $-0.658 * *$ & $-0.615^{* *}$ & $-0.591 * *$ & $0.711 * *$ & $0.793 * *$ & $-0.598 * *$ & $-0.544 * *$ & 1 & \\
\hline & Sig. (2-tailed) & 0.000 & 0.000 & 0.000 & 0.590 & 0.000 & 0.000 & 0.000 & 0.000 & & \\
\hline \multirow[t]{3}{*}{ GROWTH } & Correlation & 0.149 & 0.130 & -0.051 & -0.052 & 0.066 & 0.065 & -0.057 & -0.059 & 0.023 & 1 \\
\hline & Sig. (2-tailed) & 0.124 & 0.179 & 0.603 & 0.590 & 0.500 & 0.502 & 0.558 & 0.547 & 0.810 & \\
\hline & $\mathrm{N}$ & 108 & 108 & 108 & 108 & 108 & 108 & 108 & 108 & 108 & 108 \\
\hline
\end{tabular}

**. Correlation is significant at the 0.01 level (2-tailed).

The findings of the correlation analysis are presented in Table 3. Correlation is considered significant at the $99 \%$ confidence level. Correlation coefficients illustrate the size and direction of the relationships between the data variables.

There were thirty-six strong correlation relationships at the $99 \%$ confidence level and, eighteen were negatively correlated whilst the other eighteen had positive correlation relationships. There were nine insignificant correlation relationships at $1 \%$ level between income growth and all the other variables for the study.

Positive and significant relationships were found at the $99 \%$ confidence level between ROA and; CCTA ( $r=0.419$, $\mathrm{p}=0.000), \mathrm{CD}(\mathrm{r}=0.404, \mathrm{p}=0.000)$, LATA $(\mathrm{r}=0.398, \mathrm{p}=0.000)$ and LAD $(\mathrm{r}=0.358, \mathrm{p}=0.000)$. ROA had strong negative correlation relationships with LTA $(r=-0.451, p=0.000)$, LD $(r=-0.530, p=0.000)$, and SIZE $(r=-$ 0.597, $\mathrm{p}=0.000$ ).

Positive and significant correlations at $1 \%$ level were established between ROE and CCTA $(r=0.525, p=0.000), C D$ $(\mathrm{r}=0.509, \mathrm{p}=0.000)$, LATA $(\mathrm{r}=0.500, \mathrm{p}=0.000)$ and $\operatorname{LAD}(\mathrm{r}=0.459, \mathrm{p}=0.000)$, and strong negative correlation relationships were found with LTA $(r=-0.573, p=0.000)$, LD $(r=-0.641, p=0.000)$, and SIZE $(r=-0.658, p=$ 0.000 ).

This implies that when cash and cash equivalents to total assets, cash to deposits, liquid assets to total assets and liquid assets to deposits ratios increase, the financial performance measures of return on assets and return on equity also move in the same direction. However, in the case of loans to total assets ratio and loan to deposit ratio, they move in the opposite direction with the two performance measures respectively. 


\subsection{Regression Analysis}

The effect of liquidity management on financial performance of commercial banks was determined by regressing ROA and ROE against CCTA, CD, LD, LTA, LATA, and LAD using three staged regression that resulted in six models. Growth and Size were used as control variables that also affect the financial performance of commercial banks. Table 4 has the results of ROA as the dependent variable whilst regression results of ROE are shown in Table 5.

4.4 Dependent Variable: Return on Assets (ROA)

Table 4. Regression coefficients of the liquidity management ratios on ROA

\begin{tabular}{lccc}
\hline Independent Variables & Model 1 & Model 2 & Model 3 \\
\hline Intercept & 0.035 & 0.149 & 0.013 \\
& $(0.011)^{*}$ & $(0.215)$ & $(0.364)$ \\
\hline Cash \& Cash equivalent to Total Assets (CCTA) & 4.625 & - & - \\
& $(0.172)$ & & - \\
\hline Cash to Deposits (CD) & -4.433 & - & - \\
& $(0.180)$ & & -1.889 \\
\hline Loans to Deposits (LD) & - & $(0.000)^{*}$ & - \\
& & 1.369 & \\
\hline Loans to Total Assets (LTA) & - & $(0.003)^{*}$ & - \\
\hline Liquid Assets to Total Assets (LATA) & - & - & $(0.598$ \\
& & & -3.073 \\
\hline Liquid Assets to Deposits (LAD) & - & - & $(0.003)^{*}$ \\
\hline Natural Logarithm of Total Assets (SIZE) & -0.379 & -0.136 & -0.125 \\
& $(0.017)^{*}$ & $(0.325)$ & $(0.458)$ \\
\hline Income Growth (GROWTH) & 2.081 & 0.167 & 2.186 \\
& $(0.040)^{*}$ & $(0.015)^{*}$ & $(0.031)^{*}$ \\
\hline $\mathrm{R}^{2}$ & 0.399 & 0.538 & 0.438 \\
\hline Adjusted R & & & \\
& 0.376 & 0.520 & 0.417 \\
\hline
\end{tabular}

The p-values are in brackets with * denoting significance at $95 \%$ confidence level

The three models with results presented in Table 4 used liquidity management proxies and two control variables, size (natural logarithms of total assets) and income growth to measure their effect on ROA.

The regression equation that was used for Model 1 is as follows:

$$
\mathrm{ROA}_{\mathrm{it}}=\alpha+\beta_{1} \mathrm{CCTA}_{\mathrm{it}}+\beta_{2} \mathrm{CD}_{\mathrm{it}}+\beta_{3} \mathrm{SIZE}_{\mathrm{it}}+\beta_{4} \mathrm{GROWTH}_{\mathrm{it}}+\varepsilon
$$

Model 1 had 0.399 as its $\mathrm{R}^{2}$ implying that $39.9 \%$ of the changes in ROA can be explained by the five independent variables. The results show a statistically insignificant positive relationship for cash and cash equivalent to total assets ratio ( $p$-value $=0.172$ ) to ROA with a regression coefficient of 4.625. Cash to Deposits ratio has a negative and insignificant relationship with ROA ( $\mathrm{p}$-value $=0.180$ ) and regression coefficient of -4.433 . The two control variables had statistically significant relationships with ROA.

The findings of the study are not in line with the results of Majakusi (2012) and Bagh, Razzaq, Azad, Liaqat, and Khan (2017) who concluded that cash and cash equivalents to total assets ratio had positive and significant effect on ROA. However, they are in agreement with Islam (2018) who concluded that cash and cash equivalents to total assets ratio had an insignificant positive relationship with return on assets.

The outcome of this study agree with Mishra and Pradhran (2019) who concluded that cash to deposits ratio has an insignificant and negative relationship with return on assets. However, Osei (2019) concluded that cash to deposits ratio had a positive and significant effect on return on assets.

The regression equation that was used for Model 2 is as follows:

$$
\mathrm{ROA}_{\mathrm{it}}=\alpha+\beta_{1} \mathrm{LD}_{\mathrm{it}}+\beta_{2} \mathrm{LTA}_{\mathrm{it}}+\beta_{3} \mathrm{SIZE}_{\mathrm{it}}+\beta_{4} \mathrm{GROWTH}_{\mathrm{it}}+\varepsilon
$$


The $\mathrm{R}^{2}$ for Model 2 was 0.538 implying $53.8 \%$ of changes in ROA can be described by LD, LTA, SIZE and GROWTH. Loans to deposits ratio had a statistically significant negative relationship (p-value $=0.000$ ) with ROA whilst LTA's relationship was statistically significant ( $\mathrm{p}$-value $=0.003$ ) but positive. The regression coefficients liquidity management proxies were -1.889 and 1.369 for LD and LTA respectively.

The findings of Salim and Bilal (2019) who concluded that loans to total assets ratio had a positive and significant effect on return on assets are agreement with the study. However, the outcome of this study disagree with Sandino (2019) and Ibrahim and Aqeel (2017), who concluded that loans to total assets ratio has an insignificant and negative relationship with return on assets.

The findings of the study are further in disagreement with Ibrahim and Aqeel (2017), Shrestha (2018), Sandino (2019) and Bagh, Razzaq, Azad, Liaqat, and Khan (2017) who concluded that loans to deposits ratio had positive effect on ROA. The findings of Mishra and Pradhan (2019) and Osei (2019) are somehow in line with the study and indicate that loans to deposit ratio had a negative relationship but with insignificant impact on return on assets.

The regression equation that was used for Model 3 is as follows:

$$
\text { ROA }_{i t}=\alpha+\beta_{1} \text { LATA }_{\text {it }}+\beta_{2} \mathrm{LAD}_{\text {it }}+\beta_{3} \mathrm{SIZE}_{\text {it }}+\beta_{4} \mathrm{GROWTH}_{\mathrm{it}}+\varepsilon
$$

Model 3 had 0.438 as $\mathrm{R}^{2}$ implying that $43.8 \%$ of the changes in ROA were due to LATA, LAD, SIZE and GROWTH. LATA and LAD had statistically significant relationships with ROA with p-values of 0.002 and 0.003 respectively. The regression coefficients were 5.598 and -3.073 for LATA and LAD respectively.

The results are not consistent with finding of Onyekwelu, Chukwuaniand Onyeka (2018) and Salim and Bilal (2016), who concluded that liquid assets to total assets ratio had a negative relationship with return on assets. However, in the case of liquid assets to deposits ratio, Onyekwelu et.al, (2018) concluded that there is a significant negative relationship with return on assets which is in line with the findings of this study. The findings of Salim and Bilam (2016) are at variance with the study, when they concluded that Liquid assets to deposits had a positive and significant relationship with ROA.

These findings imply that an increase of LTA and LATA has a significant positive effect on ROA whilst for LD and LAD it is significant but with a negative effect at $95 \%$ confidence level. CCTA and CAD both have an insignificant effect on ROA.

\subsection{Dependent Variable: Return on Equity (ROE)}

Table 5. Regression coefficients of the liquidity management ratios on ROE

\begin{tabular}{lccc}
\hline \multicolumn{1}{c}{ Independent Variables } & Model 1 & Model 2 & Model 3 \\
\hline Intercept & 0.332 & 0.140 & 0.136 \\
& $(0.010)^{*}$ & $(0.266)$ & $(0.318)$ \\
\hline Cash \& Cash equivalent to Total Assets & & & \\
(CCTA) & 5.107 & - & - \\
& $(0.102)$ & & - \\
\hline Cash to Deposits (CD) & -4.798 & - & - \\
& $(0.115)$ & & -2.124 \\
\hline Loans to Deposits (LD) & - & $(0.000)^{*}$ & - \\
& - & 1.728 & \\
\hline Loans to Total Assets (LTA) & - & - & 5.611 \\
& & & $(0.001)^{*}$ \\
\hline Liquid Assets to Total Assets (LATA) & - & - & -5.197 \\
& & & $(0.001)^{*}$ \\
\hline Liquid Assets to Deposits (LAD) & -0.358 & -0.145 & -0.132 \\
& $(0.014)^{*}$ & $(0.334)$ & $(0.396)$ \\
\hline Natural Logarithm of Total Assets (SIZE) & 0.146 & 0.178 & 0.149 \\
& $(0.042)^{*}$ & $(0.016)^{*}$ & $(0.031)^{*}$ \\
\hline Income Growth (GROWTH) & 0.491 & 0.460 & 0.523 \\
\hline $\mathrm{R}^{2}$ & 0.472 & 0.439 & 0.505 \\
\hline Adjusted R & & \\
\hline
\end{tabular}

The p-values are in brackets with $*$ denoting significance at $95 \%$ confidence level 
The impact of liquidity management proxies and two control variables, size (natural logarithms of total assets) and income growth to ROE are presented in Table 5 using three models.

The regression equation that was used for Model 1 is as follows:

$$
\mathrm{ROE}_{\mathrm{it}}=\alpha+\beta_{1} \mathrm{CCTA}_{\mathrm{it}}+\beta_{2} \mathrm{CD}_{\mathrm{it}}+\beta_{3} \mathrm{SIZE}_{\mathrm{it}}+\beta_{4} \mathrm{GROWTH}_{\mathrm{it}}+\varepsilon
$$

Model 1 had 0.491 as its $\mathrm{R}^{2}$ implying that $49.1 \%$ of the changes in ROE can be explained by liquidity management proxies and control variables. The regression output show a statistically insignificant positive relationship for cash and cash equivalent to total assets ratio (p-value $=0.102$ ) to ROE with a regression coefficient of 5.107. Cash to Deposits ratio has a negative and insignificant relationship with ROA ( $\mathrm{p}$-value $=0.115$ ) and regression coefficient of -4.798. The two control variables, SIZE and GROWTH had statistically significant relationships with ROE.

The findings of the study are not in line with the results of Bagh, Razzaq, Azad, Liaqat, and Khan (2017) and Edem (2017), who concluded that there was a significant positive relationship for cash and cash equivalent to total assets ratio with return on equity.

Results of Mishra and Pradhan (2019) are agreement with the study who concluded that cash to deposits ratio has a negative and insignificant relationship with return on assets. However, the outcome of the study are not consistent with Osei (2019) who concluded that there was a positive and insignificant relationship between CD and ROE, whilst Edem (2017) also found a positive and significant relationship between CD and ROE.

The regression equation that was used for Model 2 is as follows:

$$
\mathrm{ROE}_{\mathrm{it}}=\alpha+\beta_{1} \mathrm{LD}_{\mathrm{it}}+\beta_{2} \mathrm{LTA}_{\mathrm{it}}+\beta_{3} \mathrm{SIZE}_{\mathrm{it}}+\beta_{4} \mathrm{GROWTH}_{\mathrm{it}}+\varepsilon
$$

Model 2 had 0.460 as $\mathrm{R}^{2}$ implying that $46 \%$ of the changes in ROE were influenced by LD, LTA, SIZE and GROWTH. LD and LTA had statistically significant relationships with ROE with p-values of 0.000 and 0.001 respectively. LD had a negative relationship with a regression coefficient of -2.124 whilst LTA's relationship was positive with a regression coefficient of 1.728 .

The outcomes of the study are somehow in agreement with the findings of Ibrahim and Aqeel (2017), who concluded that loans to total assets ratio positively influenced the ROE but with an insignificant effect. However, the findings of Salim and Bilal are at variance with the study, who concluded that LTA had a negative and insignificant relationship with ROE.

The results of Bagh, Razzaq, Azad, Liaqat, and Khan (2017) underscored that the loans to deposits ratio had a negative relationship with ROE that was significant are in line with the study. Mishra, and Pradhan (2019) indicate that loans to deposit ratio had a negative relationship, but with no significant impact on return on equity. However, the findings of the study are not consistent with the results of Ibrahim and Aqeel (2017) and Edem (2017), who concluded that there was a positive relationship between loans to deposit ratio and ROE.

The regression equation that was used for Model 3 is as follows:

$$
\text { ROE }_{i t}=\alpha+\beta_{1} \text { LATA }_{i t}+\beta_{2} \text { LAD }_{i t}+\beta_{3} \text { SIZE }_{i t}+\beta_{4} \text { GROWTH }_{\text {it }}+\varepsilon
$$

The $\mathrm{R}^{2}$ for Model 3 was 0.523 implying $52.3 \%$ of changes in ROE can be described by LATA, LAD, SIZE and GROWTH. Liquid assets to total assets ratio had a statistically significant positive relationship ( $p$-value $=0.001$ ) with ROE whilst LAD's relationship was statistically significant $(\mathrm{p}$-value $=0.001)$ but negative. The regression coefficients for liquidity management proxies were 5.611 and -5.197 for LATA and LAD respectively.

The study's outcomes are in disagreement with the findings of Salim and Bilal (2016) who found a negative and insignificant relationship between liquid assets to total asset ratio with return on equity. Meanwhile, the results of Salim and Bilal (2016) disagree with the findings of our study, as they concluded that there was a significant positive relationship between liquid assets to deposit ratio with return on equity.

These findings indicate that an increase of LTA and LATA has a significant positive effect on ROE whilst for LD and LAD is significant but with a negative effect at 95\% confidence level. However, CCTA and CAD both have an insignificant impact on ROE.

\section{Conclusion and Recommendation}

The main purpose of this study was to determine the effect of liquidity management on financial performance of commercial banks in Botswana. Liquidity management was assessed using cash and cash equivalents to total assets ratio, cash to deposits ratio, loans to deposits ratio, loans to total assets ratio, liquid assets to deposits ratio, and liquid 
assets total assets ratio and financial performance was measured by return on assets and return on equity. The conclusions were as follows:

In terms of loans to total assets ratio and liquid assets to total assets ratio, positive and significant relationships were established with commercial banks financial performance. Therefore, it implies that when loans to total assets ratio and liquid assets to total assets ratio increase, financial performance of commercial banks also go up.

Loans to deposits ratio and liquid assets to deposit ratio had negative significant relationships with commercial banks financial performance measured by return on assets and return on assets respectively. Therefore, an increase to loans to deposit ratio and liquid assets to deposit ratio has a significant negative impact on commercial banks financial performance.

Cash to deposits ratio had negative insignificant relationships with commercial banks financial performance measures, and is in line with the findings of Mishra and Pradhan (2019). A positive and insignificant relationship was established between cash and cash equivalents to total assets ratio viz. commercial banks financial performance measures. Therefore, an increase to cash to deposits ratio and cash and cash equivalents to total assets ratio has positive and negative insignificant effect on commercial bank financial performance measures respectively.

The study recommends commercial banks to strike a balance between financial intermediation through conversion of deposits into loans and being liquid by having liquid assets that can easily be converted into cash in order to generate the maximum profit possible. The study revealed mixed results in terms of financial intermediation and liquidity. The increase of loans to total assets ratio has a positive significant effect with financial performance whilst for loans to deposits has a significant negative effect on financial performance and it is all about financial intermediation. In terms of liquidity, an increase of liquid assets to total assets ratio has a positive significant effect on financial performance and in the case of liquid assets to deposits, it has a significant negative impact. Therefore, an optimal level for being liquid and having efficient utilization of assets to generate profits must be stricken to improve financial performance of banks. Hence policy makers through the central bank should come with initiatives to improve bank liquidity, such as among others, devising adequate minimum liquidity requirements from time to time that will keep banks profitable in their operations.

\section{Limitations \& Directions for Future Research}

Future research could consider also using primary data to triangulate the impact of liquidity on bank performance. The primary data will be specifically collected to assess the effect of liquidity management on the performance of commercial banks in Botswana in order to get more insight on the impact of liquidity on bank performance, over and above secondary data analysis. Comparative research between top and low tier commercial banks in Botswana could be held in the future to assess on the effect liquidity management to financial performance among commercial banks.

\section{References}

Abdallah, W., Goergen, M., \& O'Sullivan, N. (2015). Endogeneity: How failure to correct for it can cause wrong inferences and some remedies. British Journal of Management, 26(4), 791-804.

Agbada, A. O., \& Osuji, C. C. (2013). The efficacy of liquidity management and banking performance in Nigeria. International Review of Management and Business Research, 2(1), 223-233.

Ahmed, S. U., Ahmed, S., Islam, M. D., \& Ullah, G. M. (2015). Impact of Basel II implementation on the financial performance of private commercial banks of Bangladesh. European Journal of Economics, Finance and Administrative Sciences, (77).

Akinwumi, I. A., Essien, J. M., \& Adegboyega, R. (2017). Liquidity management and banks performance in Nigeria. Business Management and Economics, 5(6), 88-98.

Amusa, A., \& Kayawe, T. (2003). Concentration in Botswana's banking sector. South African Journal of Economic and Management Sciences, 6(4), 823-847. https://doi.org/10.4102/sajems.v6i4.1524

Ayunku, P. E. (2017). An Evaluation of Liquidity Management and Banks Performance in Nigeria: A Correlation Matrix Approach. Noble International Journal of Business and Management Research, 1(8), 123-128.

Bagh, T., Razzaq, S., Azad, T., Liaqat, I., \& Khan, M. A. (2017). The causative impact of liquidity management on profitability of banks in Pakistan: An empirical investigation. International Journal of Academic Research in Economics and Management Sciences, 6(3), 153-170. https://doi.org/10.6007/IJAREMS/v6-i3/3151

Bank of Botswana. (2019). Financial Stability Report, September 2019. Retrieved June 20, from https://bankofbotswana.bw/publication/financial-stability-report-september-2019 
Bank of Botswana. (2019). Retrieved 5 May 2020, from https://www.bankofbotswana.bw/sites/default/files/press-release-files/press-release-surrender-of-banking-licenc e-bank-india.pdf

Bank of Botswana. (2020). Monetary Policy Statement 2020. Retrieved June 20, from https://www.bankofbotswana.bw/sites/default/files/publications/Monetary\%20Policy\%20Statement\%202020_0. pdf

Bank of Botswana. (2020). Retrieved $21 \quad$ April 2020, from https://www.bankofbotswana.bw/sites/default/files/publications/BFS\%20FEBRUARY\%202020.xls

Bourke, P. (1989). Concentration and other determinants of bank profitability in Europe, North America and Australia. Journal of Banking \& Finance, 13(1), 65-79. https://doi.org/10.1016/0378-4266(89)90020-4

Businge, H. (2017). Effect of Liquidity Management on the Performance of Commercial Banks: A Case of Stanbic Bank Uganda Limited. Doctoral dissertation, Makerere University.

Dzapasi, F. D. (2020). The impact of Liquidity Management on Bank Financial Performance in a subdued economic environment: A case of the Zimbabwean Banking Industry. PM World Journal, 9(1), 1-20.

Edem, D. B. (2017). Liquidity management and performance of deposit money banks in Nigeria (1986-2011): An investigation. International Journal of Economics, Finance and Management Sciences, 5(3), 146-161. https://doi.org/10.11648/j.ijefm.20170503.13

European Central Bank. (2010), Beyond ROE - how to measure bank performance. The Report on EU Banking Structures. p. 43.

Hanson, J. (2017). Testing the Difference between School Level and Academic Mindset in the Classroom: Implications for Developing Student Psycho-Social Skills in Secondary School Classrooms. Journal of Educational Issues, 3(1), 44-63. https://doi.org/10.5296/jei.v3i1.10479

Ibe, S. O. (2013). The impact of liquidity management on the profitability of banks in Nigeria. Journal of Finance and Bank Management, 1(1), 37-48.

Ibrahim, \& Aqeel, M. (2017). Impact of Liquidity Management on Profitability in the Pakistani Commercial Banks. International Journal of Scientific \& Engineering Research, 8(7), 1459-1478.

Islam, F. (2018). A Thesis on the Relationship between Liquidity and Profitability of Listed Banks of Bangladesh. MBA research project, Jahangirnagar University, Savar, Dhaka.

Kitere, W. A. O., Namusonge, G. S., \& Makokha, E. N. (2019). Effect of Liquidity Management on Performance of Commercial Banks in Kenya. European Journal of Business and Management, 11(17), 30-41.

Lamberg, S., \& Vålming, S. (2009). Impact of Liquidity Management on Profitability: A study of the adaption of liquidity strategies in a financial crisis. Master thesis, Umeå School of Business, pp. 1-82.

Lartey, V. C., Antwi, S., \& Boadi, E. K. (2013). The relationship between liquidity and profitability of listed banks in Ghana. International Journal of Business and Social Science, 4(3).

Majakusi, J. (2016). Effect of Liquidity Management on the Financial Performance of Commercial Banks in Kenya. Unpublished MBA research project, University of Nairobi.

Marozva, G. (2015). Liquidity and bank performance. International Business \& Economics Research Journal (IBER), 14(3), 453-562. https://doi.org/10.19030/iber.v14i3.9218

Mbekomize, C. J., \& Mapharing, M. (2017). Analysis of determinants of profitability of commercial banks in Botswana. International Journal of Academic Research in Accounting, Finance and Management Sciences, 7(2), 131-144. https://doi.org/10.6007/IJARAFMS/v7-i2/2878

Mishra, S., \& Pradhan, B. B. (2019). Impact of Liquidity Management on Profitability: An Empirical Analysis in Private Sector Banks of India. Revista ESPACIOS, 40(30).

Molefe, B., \& Muzindutsi, P. F. (2016). Effect of capital and liquidity management on profitability of major South African banks. In Proceedings of the 28th Conference of the South African Institute of Management Scientists.

Molyneux, P., \& Thornton, J. (1992). Determinants of European bank profitability: a note. Journal of Banking \& Finance, 16(6), 1173-1178. https://doi.org/10.1016/0378-4266(92)90065-8 
Mucheru, E., Shukla, J., \& Kibachia, J. (2017). Effect of Liquidity Management on Financial Performance of Commercial Banks in Rwanda. A Study of Selected Banks in Rwanda. European Journal of Business and Social Sciences, 6(7), 1-11.

Muzaffar, B. (2016). The development and validation of a scale to measure training culture: the TC Scale. Journal of Culture, Society and Development, 23, 49-58.

Nabeel, M., \& Hussain, S. M. (2017). Liquidity management and its impact on banks profitability: A perspective of Pakistan. International Journal of Business and Management Invention, 6(5), 28-33.

Ndlovu, T. (2015). Determinants of commercial banks profitability in Botswana. Doctoral dissertation, University of Botswana.

Onyekwelu, U. L., Chukwuani, V. N., \& Onyeka, V. N. (2018). Effect of liquidity on financial performance of deposit money banks in Nigeria. Journal of Economics and Sustainable Development, 9(4), 19-28.

Osei, C. (2019). a thesis on Assessing the relationship between liquidity and profitability of banks listed on the Ghana Stock Exchange. Unpublished Master of Science research project, Kwame Nkrumah University of Science and Technology.

Pradhan, R. S., \& Shrestha, D. (2016). Impact of liquidity on bank profitability in Nepalese commercial banks. https://doi.org/10.2139/ssrn.2793530

Salim, B. F., \& Bilal, Z. O. (2016). The impact of liquidity management on financial performance in Omani banking sector. International Journal of Accounting, Business and Economic Research, 14(1), 545-565.

Sandino, M. A. (2019). Liquidity Management and Bank Profitability: A Case of Listed Banks on the Ghana Stock Exchange. Doctoral dissertation, University of Ghana.

Sathyamoorthi, C. R., Mapharing, M., Mphoeng, M., \& Dzimiri, M. (2019). Impact of Financial Risk Management Practices on Financial Performance: Evidence from Commercial Banks in Botswana. Applied Finance and Accounting, 6(1), 25-39. https://doi.org/10.11114/afa.v6i1.4650

Sathyamoorthi, C. R., Mapharing, M., Ndzinge, S., Tobedza, G., \& Wally-Dima, L. (2017). Performance Evaluation of Listed Commercial Banks in Botswana: The Camel Model. Archives of Business Research, 5(10), 142-159. https://doi.org/10.14738/abr.510.3783

Seemule, M., Sinha, N., \& Ndlovu, T. (2017). Determinants of commercial banks' profitability in Botswana: an empirical analysis. IUP Journal of Bank Management, 16(2), 7.

Sheikhdon, A. A. (2016). Effect of Liquidity Management on Financial Performance of Commercial Banks in Mogadishu, Somalia. International Journal for Research in Business, Management and Accounting, 2(5), 101-123.

Shrestha, B. (2018). Liquidity Management and Profitability of Commercial Banks in Nepal. International Journal of Management and Applied Science, 4(7), 98-102.

Sile, N., Olweny, T., \& Sakwa, M. (2019). Liquidity as a Determinant of Commercial Banks' Financial Performance in Kenya. International Journal of Economics, Commerce and Management, 7(1), 161-171.

Waleed, A., Pasha, A., \& Akhtar, A. (2016). Exploring the impact of liquidity on profitability: Evidence from banking sector of Pakistan. Journal of Internet Banking and Commerce, 21(3). https://doi.org/10.2139/ssrn.2899817

Ware, E. O. (2015). Liquidity management and its effect on profitability in a tough economy: A case of companies listed on the Ghana Stock Exchange. International Journal of Research in Business Studies and Management, 2(11), 1-33.

\section{Copyrights}

Copyright for this article is retained by the author(s), with first publication rights granted to the journal.

This is an open-access article distributed under the terms and conditions of the Creative Commons Attribution license (http://creativecommons.org/licenses/by/4.0/). 